\title{
Ekonomi Global dan Krisis Demokrasi
}

\section{Budi Winarno}

Jurusan Hubungan Internasional, Fakultas IImu Sosial dan IImu Politik, Universitas Gadjah Mada

Kampus Bulaksumur 55281

Email:winarno@ugm.ac.id

\begin{abstract}
Since the fall of the Soviet Union led to the end of the Cold War, democracy and capitalism have become an unchallenged ideology. In the era of globalization, global economy and free market have not directly brought about democracy, and therefore it denies the argument of globalists. As a matter of fact, globalization has increasingly marginalized the roles of state, and even it has replaced them by the non-territorial actors or the super-states, namely international institutions, multinational corporations, and private organizations. Their roles of these territorial actors not only have become so strong and dominant in economy and politics, and therefore they have the power to control the world market, but also have threatened democracy. As a result, the roles of the states are coopted to serve the interest of corporations, and are detrimental for the interest of the citizens. Therefore, conventional democracy has to be redefined because it has not been adequate any more.

Keywords:global economy, democracy, free market
\end{abstract}

\begin{abstract}
Abstrak
Sejak jatuhnya Uni Soviet menyebabkan berakhirnya Perang Dingin, demokrasi dan kapitalisme menjadi sebuah ideologi tak tertandingi. Dalam era globalisasi, ekonomi global dan pasar bebas tidak serta merta mendorong demokrasi sebagaimana argumen kaum globalis. Faktanya, globalisasi telah menyingkirkan peran negara dan diambil alih oleh aktor pasca-negara, terutama yaitu lembaga internasional, perusahaan multinasional dan organisasi swasta. Peran mereka sebagai aktor teritorial tidak hanya kuat dan dominan dalam arena ekonomi dan politik, dan karena itu mereka memiliki kekuatan mengontrol pasar dunia, namun juga mengancam demokrasi. Akibatnya, peran negara terkooptasi untuk melayani kepentingan perusahaan, dan merugikan bagi kepentingan masyarakat. Oleh karena itu, demokrasi konvensional harus didefinisikan ulang karena sudah tidak memadai.

Kata Kunci: ekonomi global, demokrasi, pasar bebas
\end{abstract}

\section{PENDAHULUAN}

Para pendukung globalisasi yang note bene adalah kaum neoliberal dalam berbagai macam bentuknya, mempunyai keyakinan bahwa ekonomi global dan pasar bebas akan mendorong demokrasi dalam skala yang luas. Oleh karenanya, pembicaraan politik tentang pasar bebas dan perdagangan bebas adalah sebuah pesan gigih yang menegaskan bahwa kemajuan pasar bebas adalah kemajuan demokrasi. Lebih lanjut, para penganjur pasar bebas akan mendorong kita untuk percaya bahwa pasar bebas merupakan mekanisme yang lebih efisien dan responsif untuk menyuarakan kehendak politik dibandingkan dengan pemungutan suara sekalipun karena bisnis lebih efisien dan lebih tanggap terhadap kebutuhan rakyat dibandingkan dengan politisi dan birokrat yang tidak memiliki kepedulian (Korten, 1997:108.)

Keyakinan ini semakin kuat ketika Uni Soviet runtuh pada dekade awal 1990-an. Akibatnya, keyakinan akan pasar bebas dan demokrasi telah menjadi doktrin umum (Chomsky, 1997). Oleh karenanya, para pendukung pasar bebas, baik mereka yang berangkat dari kalangan akademisi, politisi, maupun jurnalis akan dengan sangat lantang menyuarakan masa depan yang lebih baik, lebih adil, dan lebih demokratis melalui globalisasi dan pasar 
bebas. Sesuatu yang sebenarnya lebih merupakan preskripsi dibandingkan sebagai sebuah deskripsi realitas empiris. Franscis Fukuyama, misalnya, menyatakan bahwa ambruknya Uni Soviet membuktikan bahwa demokrasi liberal tidak mempunyai pesaing ideologi yang serius. Menurutnya, ini merupakan titik akhir dari pemerintahan manusia, dan berakhirnya Perang Dingin merupakan kemenangan dari "the ideal state", yang ditinjau dari perspektif ekonomi politik merupakan kemenangan kapitalisme liberal. Ia juga menyatakan bahwa berakhirnya konflik antara Barat dan Timur memperkuat pendapat bahwa kapitalisme liberal sekarang ini tidak tertandingi lagi, dan sekaligus merupakan model pembangunan politik dan ekonomi umat manusia.

Kemenangan kapitalisme dan demokrasi dalam pertarungan ideologis vis-a-vis komunisme Uni Soviet memang tidak dapat diragukan lagi mengingat Rusia dan bekas negara-negara Beruang Merah ini, akhirnya, mengambil demokrasi dan pasar bebas sebagai jalan politik dan ekonomi mereka. Namun, apakah globalisasi ekonomi yang sering dikhotbahkan oleh para pendukung pasar bebas akan mendorong demokratisasi adalah persoalan lain yang layak didiskusikan. Dengan kata lain, pernyataan Fukuyama benar dalam batas bahwa kapitalisme liberal sekarang ini merupakan model pembangunan ekonomi yang dianut oleh sebagian besar umat manusia abad ini, tetapi pernyataan yang menyatakan bahwa kemenangan kapitalisme liberal merupakan kemenangan "the ideal state" layak dipertanyakan. Pernyataan seperti ini masih perlu dicari relevansi pada tataran empiris ${ }^{1}$.

Sama halnya dengan hak asasi manusia (HAM) ataupun liberalisasi ekonomi, dan belakangan ini terorisme, isu mengenai demokrasi menjadi topik yang menarik untuk didiskusikan. Di penghujung abad ke20, berbagai jargon muncul untuk menggambarkan gelombang demokrasi yang melanda sebagian besar negara-negara dunia, seperti Samuel Huntington yang menyebutnya sebagai "The Third Wave" sebagai upaya untuk menggambarkan gelombang demokrasi yang melanda Afrika, Amerika Latin, Asia, dan bekas negara- negara blok Uni Soviet. Suatu survei yang dilakukan oleh Freedom House menemukan bahwa 117 negara di dunia dari sekitar 191 negara telah melakukan pemilihan umum multipartai (Scholte, 2000:263). Hal ini berarti bahwa sistem demokrasi telah dianut oleh separuh lebih negara-negara di dunia. Menunjuk data-data ini, dan didukung oleh semakin pesatnya perubahan dunia yang kini berlangsung dengan cepat, kalangan neoliberal lantas menyatakan bahwa globalisasi membawa serta demokratisasi.

Bagaimanakah demokrasi di era globalisasi sekarang ini menjadi semakin menarik untuk didiskusikan setidaknya karena lima alasan. Pertama, dengan menggunakan garis pemikiran kaum globalis, struktur ekonomi politik global sekarang ini telah mengalami banyak perubahan. Negara bangsa, dalam konteks ini, tidak lagi menjadi aktor tunggal dalam ekonomi politik internasional. Bahkan, di era globalisasi sekarang ini, diskusi mengenai negara bangsa telah usang karena perannya digantikan oleh lembagalembaga internasional dan negara-negara kawasan (Ohmae, 2002:16-17). Oleh karena itu, demokrasi konvensional sebagaimana sering dipahami tidak lagi memadai. Hal ini karena konsep demokrasi seperti adanya lembaga-lembaga perwakilan, pemilihan umum yang bebas dan adil, serta partisipasi warga negara, pada dasarnya ditujukan dalam kerangka negara teritorial yang berdaulat sehingga ketika struktur ekonomi politik internasional mengalami perubahan menurut garis pemikiran kaum globalis, demokrasi konvensional tidak lagi memadai. Dengan kata lain, diperlukan suatu definisi baru mengenai demokrasi (Scholte,2000:262). Kedua, menguatnya lembagalembaga internasional seperti WTO, IMF, dan Bank Dunia telah menjadi lembaga yang sangat berkuasa di luar negara. Bahkan, dalam kasus tertentu, lembagalembaga ini mempunyai kekuatan pemaksa yang sangat kuat terutama bagi negara-negara yang mengalami krisis $^{2}$. Ketiga, pertumbuhan perusahaan-perusahaan multinasional (MNC). Dalam beberapa dekade belakangan, seiring liberalisasi ekonomi dan perdagangan, perusahaan-perusahaan multinasional telah menjadi aktor ekonomi politik internasional 
yang semakin penting. Kekuasaan dan kekuataan ekonomi perusahaan-perusahaan ini telah mengalahkan beberapa negara nasional di dunia. Namun, berbeda dengan negara-bangsa dimana ukuran-ukuran pemerintahan demokratis adalah jelas, dalam banyak kasus, perusahaan-perusahaan ini sangat tersentralistik dan hampir tidak mempunyai akuntabilitas kepada publik. Tujuan mereka yang paling utama adalah bagaimana mengakumulasi kekayaan sebesar-besarnya. Keempat, revolusi teknologi komunikasi ternyata tidak mendorong demokratisasi sebagaimana dipreskripsikan kaum neoliberal, tetapi sebaliknya, teknologi ini telah mendorong hegemoni di bidang informasi. Dalam konteks ini, dominasi negara-negara maju tidak lagi dalam bidang ekonomi, politik, dan perdagangan, tetapi juga penguasaan informasi. Hal ini pada akhirnya akan menghancurkan pluralisme, dan menciptakan homogenisasi sehingga banyak kalangan menilai bahwa penguasaan negara-negara maju terhadap negara-negara Dunia Ketiga tidak lagi sebatas ekonomi dan politik, tetapi juga melibatkan pikiran (mind). Derasnya arus informasi yang melanda negaranegara Dunia Ketiga yang berasal dari negara-negara maju dianggap sebagai fakta yang mendukung gagasan ini.

Atas alasan-alasan inilah maka tulisan ini akan mendiskusikan bagaimana implikasi globalisasi bagi demokrasi. Apakah globalisasi, sebagaimana diyakini oleh kaum hiperglobalis, akan membawa serta demokratisasi? Jika ya, maka dalam bentuk apakah demokratisasi itu berlangsung? Atau sebaliknya, globalisasi dalam segala bentuknya akan serta merta mengancam demokrasi? Untuk menjawab pertanyaanpertanyaan tersebut, tulisan ini akan diawali dengan memaparkan makna globalisasi menurut cara pandang kaum hiperglobalis. Paparan ini penting untuk melacak logika di balik berlakunya globalisasi yang kini berlangsung dalam skala masif. Selanjutnya, akan dibahas bagaimana globalisasi telah menggeser kekuasaan individu dan entitas negara bangsa dalam ekonomi politik global. Pada akhirnya, pergeseran ini akan menciptakan elit-elit internasional baru yang bersifat poliarkhis. Tulisan ini akan ditutup dengan kemungkinan yang bisa dilakukan dalam mendorong demokrasi dalam skala global. Oleh karena negara bangsa tidak lagi menjadi pemeran tunggal dalam ekonomi politik global menurut cara pandang kaum hiperglobalis, maka usaha-usaha ke arah penciptaan demokrasi tidak lagi memadai jika hanya bertumpu pada negara-negara nasional. Untuk ini, tulisan Jan Scholte akan digunakan guna memaparkan kemungkinan-kemungkinan demokratisasi di era globalisasi sekarang ini.

\section{PEMBAHASAN}

\section{GLOBALISASI EKONOMI}

Bagi kaum hiperglobalis, globalisasi dipahami sebagai sejarah baru kehidupan manusia dimana "negara tradisional telah menjadi tidak lagi relevan, lebih-lebih menjadi tidak mungkin dalam unit-unit bisnis dalam sebuah ekonomi global. Dalam pandangan kaum hiperglobalis, globalisasi ekonomi membawa serta gejala "denasionalisasi" ekonomi melalui pendirian jaringan-jaringan produksi transnasional (transnational networks of production), perdagangan, dan keuangan. Dalam lingkungan ekonomi yang tanpa batas ini (economic borderless), pemerintahan nasional tidak lebih dari sekedar the transmission belts bagi kapital global, atau sebagai institusi perantara yang menyisip diantara kekuatan lokal dan regional yang sedang tumbuh, serta mekanisme pengaturan global (Held, 1999). Kenichie Ohmae, dalam buku The End of Nation State:The Rise of Regional Economies, menyatakan bahwa berkenaan dengan aliran riil aktivitas ekonomi, negara-negara bangsa telah kehilangan perannya sebagai unit-unit partisipasi yang bermakna dalam ekonomi dunia yang tanpa batas (Ohmae, 2002:16-17).

Ohmae menyatakan empat alasan mengapa di era global sekarang ini peran negara bangsa sudah semakin menipis. Pertama, unit-unit yang telah lama mapan dan terdefinisi secara politis ini semakin kurang memberi kontribusi-dan semakin kurangnya kebebasan untuk memberi berbagai kontribusi. Hal ini terjadi karena pasar telah semakin berdaulat, dan mereka biasa menghukum negara-negara yang tidak mampu bekerja 
secara efisien. Lebih lanjut, Ohmae menyatakan bahwa dalam ekonomi global sekarang ini, unit-unit negara bangsa sudah semakin kecil dibandingkan dengan aktor-aktor ekonomi internasional. Kerja pasar telah mengecilkan kemampuan mereka untuk mengontrol nilai tukar atau dalam melindungi mata uang mereka. Oleh karenanya, negara bangsa menjadi sangat rentan terhadap disiplin yang dipaksakan oleh pilihan-pilihan ekonomi yang dibuat di tempat lain dan lembagalembaga global yang mana mereka tidak memiliki kontrol terhadapnya. Kedua, dalam ekonomi global yang terintegrasi tersebut, negara bangsa telah menjadi fiksi nostalgik. Sekarang ini, tidaklah mungkin membicarakan ekonomi Rusia, Cina, Hongkong ataupun Jepang sebagai entitas yang berdiri sendiri. Pasar global telah menciptakan mereka ke dalam entitas yang saling terkait satu dengan yang lain. Akibatnya, pembicaraan pada entitas ekonomi nasional yang satu akan serta-merta mengaitkannya dengan entitas ekonomi yang lainnya. Ketiga, akibat semakin mengglobalnya perusahaan-perusahaan transnasional yang mana rangkaian produksinyapun juga semakin mengglobal. Oleh karena itu, menurut Ohmae, sulit untuk mengenali suatu barang yang diproduksi dan diperdagangkan dengan merujuk pada identitas nasional yang akurat. Sistem produksi telah demikian terintegrasi sehingga memungkinkan masingmasing negara-bangsa menyumbang komponen untuk produksi suatu barang. Terakhir, ketika aktivitas ekonomi secara agresif mengenakan label nasional pada saat ini, menurut Ohmae, label itu biasanya dipresentasikan bukan demi akurasi atau di luar concern terhadap kesejahteraan konsumen individual. Dengan kata lain, akibat mengglobalnya ekonomi dunia, konsumen-konsumen dunia yang berdiam dalam suatu batas teritorial negara bangsa tertentu mempunyai peluang untuk menikmati barang-barang dengan harga murah dan berkualitas tinggi, dan ini seringkali tidak diproduksi oleh industri nasional mereka.

Pertanyaannya kemudian adalah apakah yang menjadi penyebab semua ini. Dengan kata lain, faktor apakah yang menjadi pendorong munculnya globalisasi ekonomi sehingga ekonomi-ekonomi nasional menjadi semakin terintegrasi ke dalam ekonomi global, dan sistem produksi semakin terintegrasi dan mengglobal?

Bagi kalangan Strukturalis-Marxis, globalisasi ekonomi dipicu oleh kapitalisme. Oleh karena itu, globalisasi sering disebut sebagai hiperkapitalisme (Scholte,2000:112). Ini menjadi masuk akal jika kapitalisme dipahami sebagai struktur produksi yang didominasi oleh proses akumulasi surplus. Surplus ini bisa diperoleh melalui penggunaan tenaga kerja yang murah, atau bisa juga melalui penggunaan teknologi produksi. Dalam konteks ini, analisis Lenin mengenai imperialisme barangkali berguna untuk menjelaskan bagaimana kapitalisme dapat mendorong globalisasi. Menurut Lenin, kapitalisme di negara-negara Eropa Barat yang maju telah berkembang sedemikian rupa. Perkembangan ini telah mendorong terjadinya penumpukan kapital (modal) sementara keuntungan yang diperoleh dari produksi dan pasar dalam negeri semakin merosot. Oleh karena itu, mereka harus mencari pasar-pasar baru dan wilayah-wilayah baru yang dapat menjamin keberlangsungan akumulasi surplus. Dengan kata lain, mereka harus mencari sumber-sumber bahan baku untuk industri dan pasarpasar baru bagi barang-barang industri sehingga proses produksi terus berlangsung dan akumulasi keuntungan terus dapat dijamin. Selain itu, wilayah-wilayah baru ini, yang kemudian menjadi wilayah jajahan, penting sebagai tempat menanamkan investasi baru. Ketika akumulasi kapital sudah demikian besar maka usahausaha untuk menemukan tempat usaha baru melalui investasi yang menguntungkan menjadi tuntutan yang harus dipenuhi berikutnya.

Perkembangan globalisasi ini juga dipicu oleh dua faktor utama yang bertindak sebagai katalis (pemercepat), yakni revolusi di bidang teknologi komunikasi dan semakin rendahnya biaya transportasi. Hal ini karena revolusi di bidang teknologi komunikasi yang baru dimulai pada akhir tahun 1960-an, dan ditambah dengan semakin rendahnya biaya transportasi telah mengubah secara fundamental struktur ekonomi politik internasional. Anthony Giddens (2000:5), bahkan mengatakan jika globalisasi yang ditopang oleh revolusi teknologi komunikasi 
tersebut tidak hanya baru, melainkan juga

revolusioner. Revolusi di bidang teknologi komunikasi telah memungkinkan terciptanya aliran modal global yang tidak lagi dapat dihitung dalam hitungan hari, tetapi telah mengarah ke detik. Aliran investasi ini tidak hanya mendorong perkembangan ekonomiekonomi dunia di beberapa negara bangsa, tetapi sekaligus juga menghancurkan ekonomi nasional negara bangsa yang mempunyai fondasi yang rapuh dan tidak efisien. Revolusi di bidang teknologi komunikasi juga mendorong terciptanya masyarakat global (global society) yang terikat oleh adanya media informasi yang beroperasi dalam skala global. Sementara semakin rendahnya biaya transportasi, mendorong terjadinya aliran barang-barang industri dan tenaga kerja manusia melintasi batas-batas negara. Dengan demikian, jika revolusi di bidang teknologi komunikasi memungkinkan terjadinya aliran modal dalam skala global, dan menciptakan identitas global (global identity), maka revolusi di bidang transportasi udara telah mendorong aliran barang dan imigrasi tenaga kerja melintasi batas-batas negara bangsa. Akhirnya, globalisasi ekonomi menjadi terwujud karena kapitalisme membutuhkan pasar dan wilayah investasi yang lebih besar, kemudian dipercepat oleh revolusi teknologi komunikasi dan semakin rendahnya biaya transportasi yang mampu bertindak sebagai katalis.

Pada perkembangannya, kedua faktor katalis ini membuat globalisasi mampu mengubah cara mengenai bagaimana proses akumulasi terjadi. Perubahanperubahan ini berhubungan dengan luas komodifikasi, pada satu sisi, dan konteks organisasional akumulasi pada sisi yang lain (Shcolte, 2000). Dalam hal komodifikasi, globalisasi telah memacu pertumbuhan consumer capital, finance capital, dan communication and information capital. Sebagai hasilnya, kegiatan ekonomi lebih daripada sekedar memenuhi logika kapitalis. Menurut Scholte, globalisasi yang berlangsung sejak tahun 1960-an ini telah membantu memperluas jangkauan komodifikasi dalam tiga wilayah. Pertama, konsumerisme yang terhubungkan dengan produkproduk global yang diperluas oleh kapital industrial. Kedua, pertumbuhan lembaga-lembaga yang beroperasi dalam lingkup global (suprateritorial) seperti global banking dan global securities sehingga memperluas jangkauan modal uang. Lembaga-lembaga suprateritorial ini menjadi fasilitator untuk mengembangkan berbagai jenis produksi dan juga sebagai sarana akumulasi itu sendiri. Ketiga, globalisasi telah mendorong perluasan komodifikasi ke dalam wilayah baru yang melibatkan informasi dan komunikasi. Sebagai akibatnya, item-item seperti software komputer dan telepon panggil telah menjadi obyek akumulasi.

Sementara dalam konteks organisasi, globalisasi telah menghasilkan akumulasi yang terus tumbuh melalui pusat-pusat ekonomi seberang laut, dan perusahaan-perusahaan lintas batas teritorial negara bangsa. Akhirnya, globalisasi, dalam konteks ini, telah mendorong terjadinya gelombang akuisisi dan merger perusahaan-perusahaan nasional dan transnasional sehingga mendorong terjadinya konsentrasi modal.

Akhirnya, globalisasi adalah bentuk baru hegemoni ekonomi, legitimasi baru terhadap pasar, kompetisi, dan profit. Setelah dekolonisasi dan runtuhnya blok sosialis, globalisasi menjadi bentuk baru hegemoni atas nama pasar bebas, revolusi informasi, dunia sebagai satu dunia dan lain sebagainya. Akhir sejarah juga merupakan legitimasi baru bagi kapitalisme setelah runtuhnya komunisme, seolah-olah sejarah berhenti dan waktunya habis. Revolusi informasi merupakan dalih baru untuk menyatukan dunia atas nama teknologi komunikasi baru, dunia sebagai satu desa dan hukum pasar (Hanafi, 2003:69).

\section{PERGESERAN KEKUASAAN DAN KRISIS DEMOKRASI}

Salah satu perdebatan yang paling menarik, dan topik ini menjadi isu sentral dalam diskusi-diskusi mengenai globalisasi adalah menyangkut peran negara dalam ekonomi dan politik. Bagi kalangan hiperglobalis, yang pandangan-pandangannya telah banyak dikutip di awal tulisan, di era global sekarang ini, peran negara bangsa telah semakin memudar. Para politisi dan pemerintahan telah banyak kehilangan kekuasaan. Kekuatan-kekuatan yang bersifat impersonal, dalam hal ini pasar-pasar dunia, melalui 
perusahaan-perusahaan swasta dalam bidang keuangan, industri, dan perdagangan telah bekerja sama satu dengan yang lain dalam bidang ekonomi daripada melalui kerjasama pemerintahan, dan sekarang perusahaan-perusahaan ini lebih berkuasa dibandingkan dengan pemerintahan-pemerintahan nasional (Strange dalam Held, 2000:70).

Setidaknya, ada tiga aktor utama yang kini tengah menggeser kemampuan, kekuasaan, dan kedaulatan negara bangsa. Ketiga aktor nonteritorial atau Scholte menyebutnya sebagai suprastate ini, yakni lembagalembaga pengaturan global (transworld governance), perusahaan-perusahaan multinasional atau transnasional (multinational or transnational corporation), dan lembaga-lembaga swasta (NGO).

Dewasa ini, lembaga-lembaga pengaturan global seperti WTO, OECD, IMF, dan juga Bank Dunia mempunyai kekuasaan mengatur hubungan-hubungan ekonomi dan politik global yang harus ditaati oleh negara-negara anggota. Oleh karena itu, bagi kaum hiperglobalis, kemampuan mengatur pemerintahan negara-bangsa kini menjadi sangat terbatas oleh aturan yang dikeluarkan oleh lembaga-lembaga suprastate ini. Baik IMF maupun Bank Dunia telah melakukan intervensi ekonomi di lebih dari 70 negara-bangsa hingga saat ini. Di sisi yang lain, WTO juga telah menjadi lembaga pengaturan ekonomi global yang sangat berkuasa. Didukung oleh negara-negara maju seperti Jepang, Amerika Serikat, dan negara-negara Uni Eropa, lembaga inilah yang paling bertanggung jawab dalam mendorong globalisasi ekonomi yang kini telah dianut oleh separuh lebih negara-bangsa di dunia. Bahkan, lembaga-lembaga ini mempunyai kekuasaan untuk mengeluarkan sanksi bagi negara-negara anggota yang melakukan pelanggaran terhadap aturan-aturan yang telah disepakati bersama. Selain itu, konvensikonvensi internasional juga turut menggerogoti otonomi negara bangsa. Di bidang teknologi dan pengembangan senjata nuklir, otoritas negara bangsa untuk mengembangkannya, misalnya, telah semakin dibatasi oleh konvensi IAEA, sementrara di bidang lingkungan hidup terutama menyangkut emisi karbon dioksida dibatasi oleh protokol Kyoto. Pendeknya, apa yang oleh Scholte disebut sebagai rezim suprastate ini telah turut menggerogoti kekuasaan dan kedaulatan negara melalui berbagai aturan dan konvensi yang mereka tetapkan. Otonomi dan kedaulatan negara bangsa juga semakin diperlemah oleh kecenderungan munculnya regionalisme ekonomi. Antara tahun 1948 hingga tahun 1994 tidak kurang dari 109 kesepakatan regional telah dilaporkan ke GATT dengan jumlah anggota yang semakin besar memasuki era tahun 1970an dan tahun 1990-an (Scholte, 2000:146). Dari uraian ini, kita bisa menyimpulkan bahwa merosotnya kedaulatan dan otonomi suatu negara bangsa diakibatkan oleh setidaknya tiga hal. Pertama, lembagalembaga pengaturan global yang semakin dominan dalam menyelesaikan persoalan-persoalan ekonomi dan politik. Di bidang perdagangan, lembaga tersebut bernama GATT/WTO, sementara di bidang keuangan lembaga tersebut adalah IMF dan Bank Dunia. Kedua, konvensi-konvensi internasional. Kini, oleh karena adanya konvensi-konvensi ini, suatu negara bangsa tidak lagi bisa bersembunyi di balik kedaulatan dan urusan dalam negeri. Namun, pada tataran tertentu, konvensi-konvensi ini telah sedemikian jauh mencampuri urusan dalam negeri suatu negara, misalnya, karena pengembangan senjata nuklir ataupun pelanggaran hak asasi manusia. Jika suatu negara bangsa melakukan pelanggaran terhadap ketentuanketentuan konvensi ini, konsekuensi yang diperolehnya adalah pengucilan negara tersebut dari komunitas internasional atau bisa dalam bentuk pemboikotan produk-produk ekspor yang mereka hasilkan. Ketiga, lembaga-lembaga kerjasama regional seperti ASEAN, NAFTA, dan Uni Eropa. Lembaga kerjasama regional seperti Uni Eropa sedemikian jauh telah mempunyai kekuasaan yang kuat di bidang ekonomi. Mereka mempunyai mata uang dan bank sentral sendiri. Dalam situasi seperti ini, menjadi sulit bagi negaranegara anggota Uni Eropa untuk mengeluarkan kebijakan keuangan yang bertentangan dengan kebijakan bank sentralnya. Pada tataran global, integrasi ekonomi regional ini telah membuat negaranegara Eropa menjadi kekuatan ekonomi besar yang mampu menyaingi kekuatan ekonomi Jepang dan AS. 
Bahkan, dalam beberapa waktu belakangan, nilai mata uang Euro semakin menguat dibandingkan dengan dollar AS. Ini menandakan jika kekuatan ekonomi Uni Eropa telah semakin kuat dan menjadi aktor utama dalam ekonomi politik internasional, mengintegrasikan ekonomi nasional anggotanya menjadi kekuatan regional yang kuat.

Aktor transnasional kedua adalah perusahaanperusahaan multinasional atau transnasional. Beberapa penulis sebenarnya telah membuat pembedaan antara perusahaan-perusahaan multinasional dengan perusahaan-perusahaan transnasional. Namun, apapun bentuk kedua korporasi ini, cirinya yang paling utama adalah perusahaan-perusahaan ini beroperasi melintasi batas-batas teritorial negara-bangsa. Perkembangan teknologi komunikasi dan transportasi telah membuat perusahaan-perusahaan ini menjadi semakin mengglobal dengan kecepatan dan besaran yang mengesankan. Diperkirakan terdapat lebih dari 3.700 perusahaan-perusahaan multinasional dan transnasional melakukan bisnis yang tersebar di seluruh dunia. Beberapa perusahaan besar mempunyai pendapatan tahunan yang berasal dari penjualan seluruh dunia melampaui produk nasional kotor beberapa negara penting. General Motor, misalnya, pada tahun 1993 melampaui produk nasional kotor Denmark. Sementara itu, Wal-Mart mempuyai pendapatan kotor lebih besar dibandingkan dengan seluruh produk domestik kotor Polandia dalam tahun yang sama. Dalam konteks ini, kepala eksekutif General Motor dan Wal-Mart bertanggung jawab terhadap kegiatan-kegiatan ekonomi yang dikelola oleh para pemimpin politik Denmark dan Polandia (Post, 1996:178).

Ketiga, badan-badan swasta atau yang sering kita sebut sebagai Non-Governmental Organization $(\mathrm{NGO})^{3}$.Sekarang ini, setidaknya terdapat 50 ribu Ornop di Dunia Ketiga, jika digabungkan dengan yang berada di negara-negara maju tentunya jumlahnya jauh lebih besar. Khusus NGO di negara-negara Dunia Ketiga, mereka merupakan aktor-aktor politik yang penting yang bekerja di situs-situs pedalaman dan urban di Asia, Amerika Latin, dan Afrika. Dana yang mereka kelola untuk organisasi nonpemerintah yang mereka peroleh dari lembaga-lembaga keuangan internasional, agen-agen pemerintahan Eropa, Amerika Serikat, dan Jepang serta dari pemerintahan nasional mereka mencapai 10 miliar dollar AS. Perkembangan teknologi komunikasi telah memungkinkan mereka membuat jaringan kerja internasional, membahas isu yang sama untuk kemudian membuat agenda gerakan yang sama pula.

Kini, yang menjadi pertanyaan adalah apa makna pergeseran ini bagi demokrasi. Dengan kata lain, jika globalisasi, sebagaimana diyakini kaum hiperglobalis, telah menggeser kekuasaan dan kedaulatan serta kemampuan mengatur negara bangsa, dimana kekuasaan dan kemampuan mengatur tersebut telah bergeser ke aktor-aktor suprastate; apakah implikasi kecenderungan ini bagi demokrasi? Apakah dengan kecenderungan ini, globalisasi akan membawa kemajuan ataukah justru kemunduran bagi demokrasi? Untuk itu, diperlukan analisis terhadap kinerja dan sistem akuntabilitas aktor-aktor supranegara tersebut, terutama peran lembaga-lembaga pengaturan global dan perusahaan-perusahaan multinasional. Namun, sebelum itu, ada baiknya jika dikupas terlebih dahulu pandangan-pandangan beberapa ahli menyangkut hubungan antara globalisasi ekonomi, sebagai anak kandung kapitalisme, dengan demokrasi.

Dalam usaha menjelaskan hubungan antara demokrasi dan kapitalisme atau globalisasi ekonomi sekarang ini, di kalangan ilmuwan terpecah menjadi tiga kelompok ${ }^{4}$ Kelompok pertama adalah sarjana yang melihat bahwa kapitalisme "bertentangan" dengan demokrasi. Mereka berpendapat bahwa "muatan demokratis" demokrasi kapitalis adalah produk dari gerakan-gerakan rakyat dan perjuangan kelas, bukannya elemen integral dari ekspansi hubungan-hubungan pasar. Oleh karena itu, menurut pandangan ini, hasil gabungan antara kapitalisme dan demokrasi tampak sebagai sebuah perkembangan kontradiktif yang ditopang oleh equilibrium politik dimana kekuatankekuatan demokrasi harus selalu waspada terhadap kecenderungan otoritarianisme yang inheren dalam kekuasaan kapitalis. Sementara itu, berbeda dengan 
pandangan pertama yang melihat demokrasi sebagai hasil perjuangan kelas dan bukannya elemen integral dari ekspansi pasar sehingga hubungan kapitalis dan demokrasi lebih bersifat kontradiktif, pandangan kedua justru sebaliknya. Menurut pemikir yang berada dalam kelompok ini, pertumbuhan kapitalisme dan demokrasi saling terkait. Di sini, pasar-pasar yang bebas dan pemilu yang bebas dipandang sebagai prosesproses yang saling memperkuat, atau yang satu dianggap sebagai penciptaan prakondisi-prakondisi untuk yang lainnya; liberalisasi ekonomi yang membesarkan kekuatan-kekuatan perkembangan ekonomi untuk menciptakan kondisi-kondisi bagi demokrasi atau sebaliknya liberalisasi politik dan demokrasi menciptakan kondisi bagi pembangunan ekonomi ${ }^{5}$. Menurut pemikiran ini, pasar-pasar bebas memperbanyak pilihan, menumbuhkembangkan individualisme, dan memajukan pluralisme sosial, semua bumbu yang penting bagi demokrasi. Oleh karena itu, hampir segaris dengan para pemikir hiperglobalis, sebuah sistem politik yang demokratis dianggap sebagai sarana yang sangat diperlukan untuk menyelamatkan kondisi-kondisi kapitalisme yang dipandang sebagai bentuk paling efektif dan efisien pembangunan ekonomi. Baik aliran pertama dan kedua, telah mendominasi perdebatan politik dan ekonomi sejak tahun 1960-an (Petras dan Veltmeyer, 2002:194). Namun, belakangan juga telah muncul aliran pemikiran ketiga yang berpendapat bahwa wacana-wacana teoritis yang berangkat dari kedua alur pemikiran di atas melupakan sentralitas "aturan main (politik)” yang mendefinisikan demokrasi yang independen yang berasal dari gerakan-gerakan rakyat atau pasar-pasar kapitalis. Mereka berpendapat bahwa kesepakatan sosial tentang aturan main persaingan politik akan menjamin bahwa kekuatan-kekuatan politik yang bersaing akan menerima hasil-hasil pemilu dan proses demokrasi yang lain dengan asumsi pemegang kekuasaan akan mempunyai kemampuan untuk mempertahankannya, sementara kelompok oposisi mempunyai peluang yang sama untuk memperebut kekuasaan tersebut.

Uraian selanjutnya akan ditujukan untuk melacak kecenderungan globalisasi ekonomi dan implikasinya bagi demokrasi dengan melakukan analisis secara kritis terhadap lembaga-lembaga nonteritorial atau suprastate sebagai aktor-aktor penting sekarang ini di luar negarabangsa. Diharapkan melalui analisis kritis ini, kita dapat menguji ketiga pandangan di atas sehingga dapat ditemukan manakah dari ketiga pandangan tersebut yang paling relevan.

Globalisasi ekonomi atau kapitalisme global telah memunculkan aktor utama yang sangat penting dalam ekonomi politik, yakni lembaga-lembaga internasional dan korporasi-korporasi internasional yang kini semakin mengglobal. Jika korporasi menjadi aktor penting dalam menjalankan roda ekonomi melalui produksi, pemasaran, dan investasi, maka lembagalembaga global ini bertugas menyediakan aturan main yang menjamin tetap terlaksananya pasar bebas. Kedua aktor ini mempunyai kekuasaan dan kekuatan yang hampir sama, yakni dalam menggerogoti kekuasaan dan otonomi negara bangsa, dan yang paling penting adalah kemampuan dalam membelokkan demokrasi ke arah sistem poliarkhis.

Dalam hal ini, Robinson menyatakan bahwa dalam ekonomi global sekarang ini, negara-bangsa tidak hanya terkait melalui keluar masuknya uang dan hubungan antarbangsa, tetapi lebih dari itu bangsa-bangsa telah terintegrasi secara organik dalam globalisasi produksi dan distribusi itu sendiri, bersamaan dengan bersatunya keseluruhan kompleksitas politik, hukum, dan budaya (Robinson, 2003:2). Selanjutnya, mobilisasi modal secara global ini memungkinkan terjadinya sentralisasi dan integrasi fungsional seluruh bagian dunia ke dalam rantai produksi dan distribusi, perubahan nilai mata uang yang sangat cepat, dibarengi dengan pemusatan manajemen, kontrol dalam pembuatan sebuah keputusan arus modal antarbangsa. Menurut Robinson, agen-agen ekonomi global ini adalah elit transnasional baru. Elit-elit ini mengendalikan sistem keputusan dan secara cepat memonopoli kekuasaan masyarakat global. Elit-elit ini meliputi para pemilik dan manajer perusahaan transnasional, birokrat, penerus perusahaan, dan kelompok teknokrat yang terdaftar dalam lembaga- 
lembaga keuangan internasional, negara-negara utara dan selatan, dan forum antarbangsa lainnya (Robinson, 2003:4).

Pengalaman di Guatemala, misalnya, dapat dijadikan contoh kuatnya dominasi elit-elit transnasional. Seiring dengan perubahan yang terjadi antara tahun 1970 hingga tahun 1990-an, di negara ini telah terjadi pemusatan kekayaan dan kesejahteraan dan kekuasaan politik di tangan segelintir kelompok minoritas yang bersanding dengan semakin meluasnya pemiskinan dan ketidakberdayaan kelompok masyarakat mayoritas (Robinson, 2003:27). Hal ini terjadi karena kekuasaan politik di Guatemala berasal dari kekuasaan ekonomi, dan paralel dengan apa yang diungkapkan oleh Korten bahwa kekuasaan ekonomi kini telah berubah menjadi kekuasaan politik.

Sementara itu, William K. Tabb (2002:65) mengatakan bahwa adalah keliru jika memandang negara tidak berdaya dalam ekonomi global, tetapi sesungguhnya yang terjadi adalah kekuasaan negara telah secara sadar dilihat sedemikian rupa untuk mengabdi pada kepentingan korporasi, bukan kepentingan warga negara. Dalam proses ini, paham demokrasi sosial gaya Keynesianisme nasional, yang dominan sejak Perang Dunia Kedua, digusur oleh neoliberalisme global.

Menguatnya korporasi-korporasi internasional ini juga digambarkan oleh David Korten dalam hampir seluruh buku yang dia tulis, yakni When Corporations Rule the World (terbit tahun 1996) dan The Post Corporate World:Life After Capitalism (1999). Dalam paragraf pertama untuk mengawali prolog buku The Post Corporate World:Life After Capitalism yang diterbitkan oleh Centered Development Forum bekerjasama dengan Berret-Koehler Publishers, inc., ia menulis sebagai berikut.

Pada tahun 1980-an, kapitalisme menang atas komunisme. Tahun 1990-an, kapitalisme menang lagi atas demokrasi dan ekonomi pasar. Bagi sementara orang, diantara kita yang tumbuh dan dibesarkan dengan keyakinan bahwa kapitalisme merupakan fondasi demokrasi dan pasar bebas, pasti akan terkejut ketika mengetahui bahwa dalam kapitalisme, demokrasipun dapat dijual kepada penawar tertinggi, dan bahwa pasar bebas itu sebenarnya direncanakan secara terpusat oleh megakorporasi global yang ukurannya lebih besar dari banyak negara yang ada (Korten, 2002;74).

Di bagian yang lain, Korten (2002:109) menegaskan bahwa bila pasar semakin bebas dan semakin mengglobal, maka kekuatan untuk menguasai makin berpindah dari pemerintah ke korporasi global. Selanjutnya, karena desakan kompetisi yang semakin kuat, dan didorong keinginan untuk mendapatkan keuntungan sebesar-besarnya maka beberapa korporasi melakukan merger dengan korporasi lain sebagai usaha untuk meningkatkan daya saing. Merger dan akuisisi $(M \& A)$ menjadi trend baru perusahaan-perusahaan besar di era global sekarang ini. M \& A ini melibatkan perusahaan-perusahaan besar seperti Nestle, Philip Morris, RJR Nabisco, dan Unilever. Hal yang sama juga terjadi pada perusahaan-perusahaan farmasi. Pada pertengahan tahun 1990-an, misalnya, M \& A perusahaan di bidang ini mencapai 80 juta dollar AS, termasuk di dalamnya 16 transaksi senilai 1 juta dollar AS (Scholte, 2000;128), dan masih banyak lagi catatan transaksi yang melibatkan perusahaan-perusahaan besar lainnya. Akibat dari M \& A adalah jelas, yakni kekuasaan perusahaan semakin besar dan semakin memusat pada segelintir perusahaan saja. Oleh karena merger dan akuisisi ini tidak hanya melibatkan perusahaan-perusahaan kecil dengan perusahaanperusahaan besar, tetapi juga terjadi merger antara perusahaan besar (mega-merger) maka pada akhirnya hal ini akan mentransformasi pasar. Pasar menjadi tidak lagi kompetitif dan cenderung monopolistik. Perusahaan-perusahaan besar kini mendominasi banyak sektor. Sebagai contoh, pada pertengahan tahun 1990an, lima perusahaan besar masing-masing menguasai 70 persen barang-barang konsumsi tahan lama, 60 persen air travel, lebih dari 50 persen industri manufaktur pesawat terbang, lebih dari 50 persen perlengkapan elektronik, lebih dari 40 persen di bidang media global, dan 30 persen penjualan asuransi dunia. Pada tahun 1998, sepuluh perusahaan terbesar di dunia mengontrol hampir 70 persen penjualan komputer di 
pasaran dunia, 85 persen pestisida, dan 86 persen jasa telekomunikasi (Harvey, 1995:129). Data-data ini menunjukkan bahwa globalisasi ekonomi telah menghancurkan hampir sama sekali kompetisi, dan hal ini berarti kematian bagi demokrasi pasar. Di sisi yang lain, monopoli perusahaan-perusahaan besar ini, yang didukung dengan sistem penelitian dan pemasaran yang kuat, telah membuat konsumen tidak lagi mempunyai banyak pilihan sebagaimana sering dinyatakan oleh para pendukung hiperglobalis. Pada akhirnya, pilihan-pilihan konsumen lebih ditentukan oleh system marketing perusahaan-perusahaan tersebut dibandingkan dengan banyaknya jenis barang yang tersedia di pasar.

Jika analisis eksternal mengenai peran perusahaanperusahaan global ini dalam menciptakan monopoli dan mematikan kompetisi adalah jelas, analisis internal menyangkut sistem perencanaan dan pengambilan keputusan di perusahaan-perusahaan ini juga menunjukkan hal yang kurang lebih sama. Menurut Korten, perubahan yang paling ironis dalam kapitalisme global ialah ekonomi yang terjadi dalam internal korporasi yang jauh lebih banyak persamaannya dengan ekonomi yang direncanakan secara terpusat dibandingkan dengan suatu ekonomi pasar yang mengatur diri sendiri (self-regulating). Menyangkut sistem perencanaan dan pengambilan keputusan di tingkat korporasi global ini, Korten menuliskannya sebagai berikut.

Dalam sistem di Amerika Serikat tentang paham libertarianisme korporasi dan keuangan, yang dengan cepat menulari Eropa, Jepang, dan bagian dunia yang lain, tidak peduli kewibawaan apa yang mungkin didelegasikan kepada CEO, wewenang itu dapat saja ditarik kembali kapanpun. Pada gilirannya, CEO dapat mempekerjakan orang dan memberhentikan siapapun, membuka dan menutup pabrik manapun, mengubah harga transfer, menciptakan dan menghilangkan saluran produksi, dapat dikatakan sekehendak hatinya-tanpa diprotes dalam bentuk yang signifikan oleh orang atau masyarakat yang terkena (Korten, 2002:74).

Selanjutnya, dengan mengambil salah satu contoh perusahaan global dengan PDB yang jumlahnya kirakira sama dengan PDB sebuah negara, Korten mengatakan bahwa lima puluh satu dari seratus ekonomi terbesar dunia adalah ekonomi internal terhadap korporasi itu sendiri. Lagi pula, korporasikorporasi terbesar di dunia tersebut terlibat aktif dalam hubungan perencanaan di kalangan mereka sendiri melalui asosiasi industri, aliansi strategis, dan kartel; mempengaruhi kebijakan ekonomi melalui lobilobi yang agresif; dan membentuk kembali peraturanperaturan ekonomi global melalui partisipasi mereka dengan pemerintahan mereka dalam perundinganperundingan perdagangan dan persetujuan investasi. Selangkah demi selangkah, melalui lembaga-lembaga seperti WTO dan IMF, perusahaan-perusahaan itu telah membentuk instrumen-instrumen dari suatu proses perencanaan ekonomi terpusat yang seluruhnya tidak demokratis di tingkat global.

Dalam situasi seperti ini, dalam pandangan Korten, sistem perencanaan terpusat korporasi-korporasi global ini jauh lebih baik dengan sistem perencanaan ekonomi terpusat ala Uni Soviet. Hal ini karena sistem perencanaan ekonomi Uni Soviet ditujukan untuk kepentingan masyarakat mereka sendiri, sementara sistem perencanaan terpusat perusahaan-perusahaan global ini ditujukan untuk melipatgandakan hasil yang ditujukan untuk keuntungan para pemegang saham. Dengan kata lain, tingkat kesejahteraan yang dinginkan oleh kedua sistem perencanaan terpusat ini hampir sama sekali berbeda. Pada yang pertama perencanaan terpusat ditujukan untuk akumulasi kapital dan keuntungan pemilik modal, sementara untuk yang kedua, demi "kesejahteraan" rakyat. Singkatnya, kemenangan imperium kapitalisme global berarti lebih dari separuh dari seratus ekonomi dunia yang besarbesar direncanakan secara terpusat terutama sekali untuk keuntungan 1 persen penduduk terkaya di dunia. Dengan kalimat yang sarkastis, Korten menyatakan, "Itulah kemenangan perencanaan terpusat yang dipartikelirkan terhadap pasar dan demokrasi! Bahkan lebih dari itu, inilah kemenangan pihak yang keterlaluan kayanya terhadap umat manusia sisanya yang miskinnya juga keterlaluan! (Korten, 2002:75)" 
Oleh karena itu, liberalisme, baik dalam variasi politik maupun ekonominya, telah gagal menghilangkan hierarkhi kelembagaan yang menindas, pemerintahan elit, pengesampingan mayoritas, dan penindasan potensi menata-diri dari masyarakat yang hidup. Pada akhirnya, pencarian liberal tersebut telah mengganti monarki dengan korporasi dan negarabangsa yang seringkali sama menindasnya dan sama tidak bertanggungjawabnya, yaitu sebagai akibat dari gagalnya baik kaum liberal politik maupun liberal ekonomi untuk menyesuaikan diri dengan kebenaran yang sesungguhnya yang menyatakan bahwa tidak akan ada kebebasan tanpa pertanggung-jawaban individu (Korten, 2002:171).

Uraian berikutnya akan ditujukan untuk membahas institusi-institusi global, yakni World Trade organization (WTO), International Monetary Fund (IMF), dan World Bank (Bank Dunia). Dalam rangka memahami kecenderungan globalisasi dan implikasinya bagi proses demokrasi dunia, analisis mengenai perusahaanperusahaan multinasional saja tidak cukup. Segaris dengan pandangan hiperglobalis, pembahasan mengenai negara bangsa tidak lagi signifikan karena kekuasaan otoritatif negara bangsa telah dilemahkan oleh aktor-aktor suprastate, diantaranya adalah MNC dan lembaga-lembaga pengaturan global. Oleh karena itu, analisis terhadap lembaga-lembaga ini sama pentingnya dengan analisis terhadap MNC-MNC.

Sejak awal berdirinya, ketiga institusi tersebut dibentuk untuk bermain pada skala yang melampaui batas-batas negara, suatu ciri struktur governance global yang melayani kepentingan korporasi transnasional dan keuangan internasional (Tabb, 2002:73). IMF dan Bank Dunia diciptakan pada tahun 1944 oleh AS dan Inggris, dan beberapa negara lainnya yang diundang untuk mendukung dan bergabung tanpa mampu berperan banyak dalam mendesain aturan klub-klub tersebut. IMF berwenang mengawasi stabilitas nilai tukar dengan memberi pinjaman pada negara-negara yang dalam jangka pendek memerlukan bantuan keuangan untuk menyeimbangkan anggarannya. Bank Dunia, yang kemudian disebut sebagai International Bank for Reconstruction and Development (IBRD), saat itu bertugas memberikan bantuan kepada Eropa untuk pemulihan ekonomi pascaperang. Selanjutnya, WTO didirikan pada tahun 1995, meskipun embrio organisasi ini sebenarnya telah ada sejak lama.

Institusi global inilah yang tengah mempersiapkan kebijakan bagi sebagian besar atau mayoritas negara. IMF menyediakan utang bagi negara-negara debitur dengan persyaratan ketat yang memungkinkan IMF untuk melakukan restrukturisasi ekonomi. Sementara itu, Structural Adjustment Bank Dunia juga menggunakan panduan yang serupa, dan mendorong kecenderungan yang sama dalam mensubordinasikan kebijakan domestik, terutama kebijakan yang berhubungan dengan proteksi dan subsidi. Keduanya lazim disebut sebagai Konsensus Washington.

Konsensus ini menekankan liberalisasi pasar, privatisasi BUMN, dan kebijakan lain yang dirancang untuk mendorong investasi asing, termasuk dalam hal ini devaluasi dan deregulasi (Tabb, 2002:76).

Dengan demikian, jika liberalisasi ekonomi dan perdagangan dapat dianggap sebagai proyek kaum neoliberal yang lebih bersifat ekonomi sebagai upaya untuk melakukan akumulasi kekayaan melalui lembaga-lembaga transnasional tadi, maka "demokrasi" menjadi proyek politik mereka. Hal ini dapat disaksikan dari berbagai proyek liberalisasi ekonomi dan perdagangan yang juga diikuti oleh proyek-proyek demokratisasi politik di negara yang bersangkutan. Namun, hal ini hendaknya harus dilihat secara hatihati. Seperti halnya pernah ditegaskan oleh William K. Tabb maupun Noam Chomsky, proyek demokratisasi pada intinya adalah sebuah bualan belaka. Menurut kedua penulis ini, proyek demokratisasi harus dilihat dalam kaca mata kepentingan negara dominan, dalam hal ini Amerika Serikat. Bagi negara-negara maju, sistem politik otoriter dan proteksionis hampir dapat dipastikan menjadi penghalang utama masuknya investasi perusahaan-perusahaan multinasional negaranegara maju. Jika hal ini dibiarkan, maka akan menghalangi perusahaan-perusahaan multinasional untuk meraih keuntungan maksimal dari berbagai sumber daya yang mungkin ditawarkan oleh negara tersebut, sementara dilihat dari perspektif politik, hal 
ini akan menyulitkan negara-negara besar untuk melakukan semacam "infiltrasi" politik ke negaranegara Dunia Ketiga. Oleh karena itu, untuk menjamin investasi perusahaan transnasional bisa masuk, dan negara maju dapat melakukan kontrol terhadap negara-negara Dunia Ketiga maka demokrasi menjadi agenda reformasi berikutnya.

\section{PERAN AS DALAM MENDORONG DEMOKRASI}

Pembahasan mengenai AS setidaknya dilatarbelakangi alasan bahwa AS merupakan kekuatan yang besar, dan memiliki dampak yang menentukan dalam sejarah dunia kontemporer. Sejak keruntuhan Uni Soviet, negara AS menjadi satu-satunya negara adidaya yang tidak tertandingi lagi. Keunggulannya di bidang ekonomi, politik, dan militer memberikan syarat-syarat bagi AS untuk menjadikannya sebagai negara adidaya. Selain itu, keberadaan negara adidaya yang krusial ini, sebenarnya dapat memainkan peran yang cukup besar dalam mendorong proses demokrasi di dunia dengan cara memfasilitasi gerakan-gerakan demokrasi lokal. Hal ini karena pada dasarnya, keberhasilan proses demokratisasi, seperti ditunjukan oleh Scholte, hanya akan berhasil jika gerakan-gerakan prodemokrasi di tingkat lokal mempunyai kekuatan yang cukup, sementara di negara-negara di mana gerakan prodemokrasi di tingkat lokal lemah, Afghanistan sebagai contohnya, proses demokratisasi cenderung terhambat. Di sisi yang lain, bantuan ekonomi ke negara-negara dunia ketiga, pada dasarnya, dapat digunakan untuk menekan negara-negara otoriter guna membuka sistem politiknya menjadi lebih demokratis. Namun, yang menjadi soal adalah mengapa proses demokratisasi yang sering disponsori AS seringkali gagal, dan masa depan demokrasi di banyak negara tetap suram dan cenderung mengalami kemunduran?

Jawaban terhadap pertanyaan ini dapat kembali dirujuk pada paparan di atas. Seperti telah ditegaskan sebelumnya, globalisasi ekonomi telah mendorong kekuatan ekonomi untuk merepresentasikan dirinya menjadi kekuatan dan kekuasaan politik. Akibatnya, negara-bangsa tidak lagi mengabdi kepada kepentingan warga negara sebagai konstituen politik terbesarnya, melainkan lebih mengutamakan kepentingan korporasi. Bahkan, jika dibandingkan dengan era merkantilisme, kondisi sekarang ini nampaknya jauh lebih buruk. Pada era merkantilisme, negara didorong untuk mengamankan kepentingan nasionalnya melalui pengumpulan kekayaan dengan menggunakan sumber daya yang mereka miliki, termasuk dalam hal ini keunggulan militer. Mereka saling berkompetisi satu dengan yang lain untuk mendapatkan emas, perak, dan sumber-sumber kekayaan lainnya. Namun, di era globalisasi sekarang ini, dalam beberapa kasus, intervensi negara lebih ditujukan untuk memenuhi kepentingan korporasi.

Suatu studi yang dilakukan oleh Edward Herman dari Wharton School University of Pennsylvania menunjukkan hal ini (Chomsky, 2002:43). Pada awalnya, ia melakukan studi mengenai relasi antara tingkat penyiksaan dengan bantuan AS. Hasilnya menunjukkan bahwa tingginya tingkat penyiksaan mempunyai korelasi positif dengan besarnya bantuan AS. Dengan kata lain, suatu negara yang mendapatkan bantuan AS dalam jumlah besar cenderung mempunyai tingkat penyiksaan yang tinggi terhadap warganya. Selanjutnya, studi tersebut diperluas dengan melihat korelasi antara bantuan AS dengan faktorfaktor yang lain, dan salah satu korelasi yang paling signifikan adalah antara perbaikan iklim investasi dengan bantuan AS. Begitu suatu negara berusaha memperbaiki iklim investasinya maka bantuan AS cenderung meningkat. Selanjutnya, korelasi antara bantuan AS dengan meningkatnya kekerasan dalam suatu negara dapat dilihat dalam alur berfikir sebagai berikut. Pada saat suatu negara hendak memperbaiki iklim investasinya bagi investor asing, yang tentunya sebagian besar perusahaan-perusahaan multinasional, maka bantuan AS cenderung meningkat. Sementara itu, perbaikan iklim investasi dicapai melalui program stabilisasi politik, dan hal ini diraih melalui tindakantindakan represif terhadap gerakan-gerakan buruh, petani, gerakan-gerakan prodemokrasi, dan programprogram pengamanan sosial.

Alasan kedua mengapa AS cenderung gagal dalam 
mendorong demokratisasi di banyak negara lebih disebabkan kuatnya kepentingan AS untuk mengamankan kepentingan ekonomi-politiknya sendiri dibandingkan dengan untuk mendorong proses demokratisasi yang sungguh-sungguh. Seperti telah ditegaskan di awal, agenda demokratisasi yang dicanangkan oleh AS untuk beberapa negara, seperti Irak dan Afghanistan, hanya untuk negara-negara yang tidak mendukung AS. Sementara itu, bagi negaranegara otoriter yang tetap mendukung kepentingan AS, agenda demokratisasi bukan merupakan hal penting untuk dibahas. Dalam konteks ini, seorang penulis mengatakan bahwa seringkali kita menghujat rezim Soeharto karena otoriter dan menindas demokrasi, tetapi kita hampir sama sekali tidak pernah menghujat AS karena telah "menjaga” rezim Soeharto dengan memberikan bantuan ekonomi dan militer selama hampir 30 tahun. Padahal, bantuan militer inilah yang digunakan untuk menindas rakyat Timor Timur, Aceh,dan gerakan prokemerdekaan di Irian Jaya.

Alasan ketiga adalah meluasnya terorisme. Diakui atau tidak, terorisme merupakan fenomena yang kini menjadi semakin mengglobal. Jika persoalan terorisme ini tidak dapat diselesaikan dengan cepat, maka ia akan menjadi ancaman yang serius bagi masa depan demokrasi. Di sisi yang lain, oleh karena terorisme telah menjadi sangat mengglobal dan mengancam kepentingan AS, maka negara ini mempunyai banyak alasan untuk melakukan intervensi di banyak negara guna memaksakan kepentingannya, termasuk dalam hal ini menggulingkan suatu rezim pemerintahan yang berkuasa. Seperti ditegaskan oleh William K. Tabb, yang pendapatnya banyak dikutip dalam uraian sebelumnya, bahwa isu teorisme kini telah menjadi seperti halnya ketakutan kepada "komunis" di masa lampau, dan telah menjadi alat ideologis yang kuat untuk mempertahankan kepentingan imperialis, dalam hal ini perusahaan-perusahaan multinasional AS (Tabb, 2002:xiv). Selain itu, ketakutan akan terorisme telah membuat dinas intelijen semakin berkuasa dalam memantau gerak-gerik warga negara, dan tentunya menjadi ancaman demokrasi yang paling serius. Ambil contoh, misalnya, laporan Kompas tanggal 27 Februari 2004. Pada laporan ini disebutkan permintaan dinas intelijen AS kepada dinas intelijen Inggris untuk memasang alat penyadap di kedutaan negara-negara yang turut menentukan voting di DK PBB mengenai rencana AS melakukan invasi ke Irak, termasuk dalam hal ini menyadap Sekjen PBB Koffi Anan. Sementara itu, GCHQ atau Government Communications Headquarters milik Inggris yang bermarkas di Cheltenham, Gloucestershire, yang menjadi tempat konspirasi itu terkuak, juga dapat dianggap sebagai tanda betapa di era global sekarang ini privasi warga negara menjadi semakin rentan oleh campur tangan negara. Bagaimana tidak, jika lembaga yang dibentuk pada waktu Perang Dunia Kedua dan bertugas memecahkan pesan sandi Jerman itu, kini, dilengkapi dengan teknologi yang sangat canggih yang mampu menangkap secara virtual percakapan siapapun di dunia (Kompas, 27 Februari 2004). Dengan demikian, sama halnya dengan globalisasi yang menciptakan kekuatan-kekuatan baru yang multipolar, maka di era globalisasi sekarang ini, ancaman demokrasi juga menjadi multifacet.

\section{KESIMPULAN}

Dari paparan di atas dapat diambil kesimpulan bahwa perkembangan kapitalisme pada dasarnya cenderung meningkatkan kekuasaan modal atas masyarakat, baik sebagai konsumen, warga negara ataupun sebagai pekerja. Dalam konteks hubungan antara globalisasi dan demokrasi, hampir sama sekali tidak ada satu data empiris pun yang dapat digunakan untuk mendukung proposisi kaum neoliberal bahwa globalisasi dan pasar bebas adalah inheren. Sebaliknya, globalisasi yang telah menggerogoti kekuasaan negara bangsa melalui lembaga-lembaga pengaturan dan keuangan global serta perusahaan-perusahaan multinasional telah mengancam demokrasi itu sendiri dalam segala bentuknya. Sentralisme dalam perencanaan dan proses pengambilan keputusan yang terjadi dalam perusahaan-perusahaan multinasional, dan model pengambilan keputusan di lembagalembaga internasional melalui konsensus dan lobi menunjukkan betapa tidak demokratisnya lembaga- 
lembaga tersebut. Selain itu, kecenderungan perusahaan-perusahaan multinasional untuk melakukan merger dan akuisisi membuat pasar tidak lagi kompetitif. Ini pada akhirnya menjadi ancaman bagi demokrasi pasar. Di sisi yang lain, oleh karena kekuatan ekonomi telah menjelmakan dirinya menjadi kekuasaan politik seperti dalam kasus di Guatemala, maka pemerintahan nasional menjadi tidak demokratis karena kekuasaan tidak direpresentasikan untuk kepentingan rakyat, melainkan untuk kepentingan korporasi-korporasi global. Dalam konteks ini, rakyat hanya menjadi pangabsyah rezim yang berkuasa tanpa mempunyai kekuasaan untuk melakukan kontrol terhadapnya.

Di luar itu, demokrasi juga mendapatkan tantangan dari aksi-aksi terorisme yang kini mengancam hampir seluruh negara di dunia. Untuk menanggulangi aksiaksi terorisme ini, negara-negara menjadi semakin represif dan dinas intelijen menjadi semakin kuat untuk mencampuri privasi kehidupan warga negara demi alasan kepentingan nasional. Akhirnya, demokrasi memang berada dalam krisis.

Menghadapi situasi seperti ini, untuk mengembalikan demokrasi dalam arti yang sebenarnya nampaknya perlu dicari pendekatan baru. Seperti ditegaskan oleh Scholte, jika demokrasi merupakan suatu kesatuan historis dan kultural, dan jika demokrasi telah membawa perubahan yang signifikan dalam pemerintahan, dan selanjutnya kita mengikuti konsep demokrasi dengan memusatkan pada negara nasional, maka konsep demokrasi konvensional tadi menjadi tidak memadai lagi dalam suatu lingkungan yang telah berubah dimana perusahaan-perusahaan multinasional dan lembaga-lembaga internasional semakin berkuasa, dimana ancaman terorisme menghantui siapapun di dunia, dan kekuasaan negara semakin berkurang. Untuk itu, demokrasi perlu pendefinian ulang. Dalam hal ini Peter F. Drucker memberikan saran bahwa dalam suatu lingkungan yang berubah dengan cepat ini, ada beberapa hal yang harus dilakukan, yaitu demokrasi harus mendapatkan kembali kontrol terhadap kebijakan-kebijakan domestik, ekonomi, dan fiskal sebagai akibat kebangkrutan paham ekonomi negara defisit Keynesian; menghentikan dan mengembalikan kerusakan dan meluasnya kehancuran masyarakat domestik akibat kegagalan negara kesejahteraan (welfare state); dan mempromosikan masyarakat sipil. Selain itu, perlu diketahui bahwa meskipun pasar bebas secara ekonomi efektif, tetapi ia tidak dapat bekerja sendiri dan menjaga fungsi masyarakat tetap berlangsung (Drucker, 1995:263).

\section{CATATAN AKHIR}

1 Lihat pengalaman negara-negara Amerika Latin ketika mereka mengadopsi kebijakan neoliberal, dan kasus-kasus dimana Amerika Serikat mendukung rejim otoriter di Afrika dan beberapa negara Asia Timur, Singapura, Taiwan, dan Indonesia.

2 Melalui program-program yang disebut sebagai structural adjusment biasanya lembaga-lembaga ini "memaksa" negara-negara yang mengalami krisis untuk mengadopasi kebijakan ekonomi seperti yang mereka sarankan, beberapa pengalaman mengenai hal ini dapat dilhat dalam tulisan Carlos Heredia dan Mary Purcell, 2003, "Penyesuaian Struktural di Meksiko:Akar Krisis", dalam William Robinson at. al., Hantu Neoliberalisme, Jakarta:C-Books.

3 Untuk tulisan mengenai Organisasi Non-Govermental (NGO) ini, dapat dilihat dalam tulisan James Petras dan Henry Veltmeyer, 2002, Imperialisme Abad 21 (Yogyakarta:Kreasi Wacana), bab 8.

4 Untuk pembahasan ini lihat Petras dan Veltmeyer, ibid, bab. 6.

5 Namun, studi yang dilakukan oleh Georg Sorensen menegaskan bahwa tidak ada hubungan yang saling komplementer antara pembangunan ekonomi dengan demokrasi. Di negara-negara Asia Timur yang kini masuk ke dalam kategori NICs, pembangunan ekonomi dilakukan dalam suatu sistem politik otoriter, dan bukannya dalam suatu sistem politik demokratis. Malahan, sentralisme kekuasaan dan kuatnya birokrasi menjadi salah satu faktor pendukung keberhasilan pembangunan ekonomi karena rezim yang berkuasa tidak mendapatkan tantangan yang berarti dari kelompok-kelompok oposisi mengingat keberadaan mereka telah dilemahkan oleh rezim yang berkuasa. Lihat Georg Sorensen, 2003, Demokrasi dan Demokratisasi:Proses dan Prospek dalam Dunia yang Berubah, Yogakarta:Pustaka Pelajar dan CCSS.

\section{REFERENSI}

Baradat, Leon P. 1991. Political Ideologies: Their Origin and Impact. Engliwood Cliffs, New Jersey:Prentyice Hall.

Chomsky, Noam. 1997. "Market Democracy in a Neoliberal Order:Doctrines and Reality", makalah download dari http:// www.zmag.org/chomsky/index.cfm. 2002. Power and Terror:Perbincangan Pasca Tragedi WTC 11 September 2001. Yogyakarta:Ikon

Drucker, Peter F.. 1995. Managing in a Time of Great Change. Oxford:Butterworth-Heinemann.

Giddens, Anthony. 2000. Run Way World:Bagaimana Globalisasi Merombak Kehidupan Kita. Jakarta:Gramedia. 
Hanafi, Hasan. 2003. Cakrawala Baru Peradaban Global:Revolusi Islam untuk Globalisme, Pluralisme, dan Egalitarianisme Antarperadaban. Yogyakarta:IRCiSoD.

Held, David at. al.. 1999. Global Transformation:Politics, Economics, and Culture. Stanford:Standford University Press.

Held, David and Anthony McGrew (eds.).2000. The Global Transformations Reader. Cambridge:Polity Press.

Heredia, Carlos dan Mary Purcell. 2003. "Penyesuaian Struktural di Meksiko:Akar Krisis", dalam William Robinson at. al., Hantu Neoliberalisme, Jakarta:C-Books.

Kompas, 27 Februari 2004.

Korten, David.1997. When Corporations Rule the World (Ketika Korporasi Menguasai Dunia.Jakarta:Professional Books.

2000. The Post Corporate World (Kehidupan Setelah Kapitalisme). Jakarta:Yayasan Obor.

Ohmae, Kenichie. 1995. Hancurnya Negara Kawasan:Bangkitnya Negara Kawasan dan Geliat Ekonomi Regional di Dunia tak Terbatas. Yogyakarta:Qalam

Petras, James dan Henry Veltmeyer. 2002. Imperialisme Abad 21. Yogyakarta:Kreasi Wacana.

Post, James E., et. al. 1996. Business and Society:Corpoorate Strategy, Public Policy, Ethics. Boulder and London:Lynne Reiner Publisher.

Robinson, William I.. 2003. "Neoliberalisme, Elit Global, dan Transisi Guatemala:Sebuah Analisis Kritis Makrostruktural" dalam William I. Robinson, (ed.), Hantu Neoliberalisme. Jakarta:C-Books.

Scholte, Jan Art. 2000. Globalization: A Critical Introduction, New York:St. Martin Press

Sorensen, Georg.2003. Demokrasi dan Demokratisasi:Proses dan Prospek dalam Sebuah Dunia yang Sedang Berubah, Yogyakarta:Pustaka Pelajar with CCSS.

Strange, Susan, 2000, "The Declining Authority of State", dalam David Held dan Anthony McGrew (eds.). The Global Transformations Reader: An Introduction to the Globalization Debate. Cambridge:Polity Press

Tabb, William K..2002. Tabir Politik Globalisasi.Yogyakarta:Lafadl. 